\title{
TEJÁGAZATI HELYZETKÉP
}

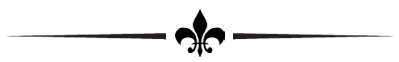

THE SITUATION OF DAIRY INDUSTRY

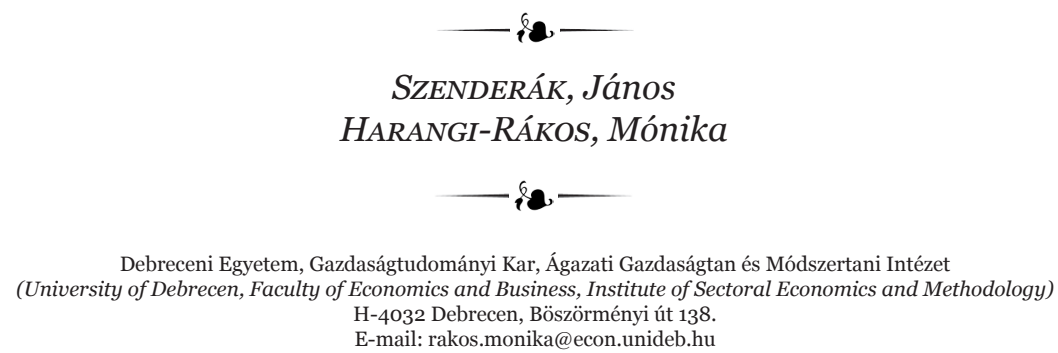

E-mail: rakos.monika@econ.unideb.hu

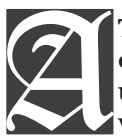

The increasing household incomes change the volume and the structure of the human consumption. There is a strong correlation between the changes in diet and the rapid urbanisation. Moving to the urban area often coincedes with a higher level of lifestyle which in turn can decrease the share of the agriculture labor force. Nowadays, more than half of the population lives in urban areas, but this share can be $70 \%$ until 2050 (FAO, 2011). Milk and dairy products are major items in the changing consumption structure. The consumers with mostly starch based diets are likely to shift to higher added value products when their income per capita increases. Majority of these products are milk and dairy or meat products. On the supply side, weather shocks can abruptly change the production volume and as a supply shock, they may increase the food price volatility. In the recent years, the gap remained constant between the production and the consumption, thus food prices have decreased (FAO, 2017). Between 1960 and 2010, the population has increased by some $230 \%$, while the meat consumption by $450 \%$ (from 65 million tons to 290 million tons) (OECD - FAO, 2017). While the meat production and export are expected to increase moderately, the EU milk production may expand by $1 \%$ and its share from the international agricultural trade will increase in the future. The EU's dairy sector aims to achieve a more marketoriented framework, which affects the Hungarian stakeholders as well. The processing and retail segment can be characterised with high concentration and strong bargaining power in general. Dairy sector appears to be purely demand-driven. The level of the individual stakeholders' cost price is not taken into account during the market's price setting, which creates strong competition. In the next years, higher market competition and further concentration are expected. Market position will be determined by one's competitiveness and the level of cooperation among the stakeholders.

\section{BEVEZETÉS - INTRODUCTION}

A fejlett országokban az elmúlt évtizedekben szerkezeti változások zajlottak le a tejiparban. Az átlagos állománylétszám nőtt, a gazdaságok száma csökkent, miközben a tej termelése intenzívebb lett a fejlett és a fejlődő országokban egyaránt. Ezek a változások az agrárkereskedelem változásával és a gazdasági liberalizációval együtt jelentősen átrendezhetik a tejtermelés jelenleg ismert földrajzi eloszlását (HEMME et al., 2014). Az elmúlt tíz évben mért éves átlagos növekedésre alapozva 2030-ra a globális tejtermelés várhatóan eléri majd az 1 milliárd tonnát, ami évi 16 millió tonna termelésbővülésnek felel meg. A termelésbővülés 35\%-át India adja, ahol továbbra is a friss tejtermékek iránti kereslet fog bővülni, ugyanakkor a termelésbővülés nagy része belföldi fogyasztási célokat szolgál majd, így India kereskedelemben betöltött szerepe mérsékelt marad. Kínában a tejtermelés bővülésének mértéke elmarad majd 
Indiától (700 ezer tonna évente). Más ázsiai országokban ennél jelentősebb termelésnövekedés (évi 2,3 millió tonna) várható, elsősorban Pakisztán termelésének köszönhetően. Afrikában a termelés évente átlagosan 1,3 millió tonnával emelkedik, elsősorban a Kelet-Afrikában található országok növekvő termelésének köszönhetően (EUROPEAN COMMISSION, 2017).

A fejlett országok és országcsoportok közül az Európai Unió termelésnövekedése (évi átlagban 1,4 millió tonna) meghaladja Új-Zéland és az USA termelésének bővülését, akik a fő versenytársaknak tekinthetőek a nemzetközi piacon. Ez azonban várhatóan csak a mennyiségre lesz igaz, hiszen százalékos értékben valószínűsíthetően a versenytársak termelésének emelkedése lesz jelentősebb. A termelékenység növekedése várhatóan folytatódik, de elmaradva az elmúlt évtizedek ütemétől (EUROPEAN COMMISSION, 2017).

Az előrejelzések szerint az Amerikai Egyesült Államokban a tejtermelés évi 1\%-kal emelkedik, miközben a tejelő állatállomány földrajzi elhelyezkedése egyre nagyobb mértékben kerül Kaliforniától keletre, közelebb a fogyasztás központjaihoz. A belföldi piac bővülése továbbra is felszívja a növekvő tejtermelésből származó növekményt, részint a népesség emelkedésének (évi 0,7\%), részint pedig az egy före jutó tejfogyasztás gyarapodásának köszönhetően (EUROPEAN COMMISSION, 2017).

A FAO (2018) adatközlése szerint a globális nyerstej termelésében az EU a legjelentősebb szereplő a világtermelés $24 \%$-ával, amelyet az USA és India követ 15 és $12 \%$-os részesedéssel. Kína állította elő a globális nyerstejtermelés 5,5\%-át, Brazília pedig az 5\%-át. A fejlett országokban a tejtermelés szinte kizárólagosan a tehéntejre koncentrálódik. India esetén azonban jelentős a bivalytej termelése, amelylyel számolva a sorrend jelentősen változna, és India kerülne az első helyre. 2016-ban a világ összes tejtermelése elérte a 798 millió tonnát. Ebból India 159 millió tonnát, az EU 163 millió tonnát, míg az USA 96 millió tonnát állított elő (FAO, 2018). Ez az adat is azt támasztja alá, hogy az EU és az USA a tehéntej termelésére specializálódott, India esetében azonban közel 82 millió tonna tej más forrásból, elsősorban a bivalytartásból kerül ki.
Azoknál az ázsiai és afrikai országoknál, amelyek még nem önellátóak, a termelés várhatóan jelentős mértékben emelkedik majd, de még ez sem lesz elegendő a tej iránti növekvő kereslet kielégítéséhez. Folytatódik továbbá a teljes tejpor (WMP), a sovány tejpor (SMP), a sajt és a vaj világkereskedelmének bővülése is, várhatóan évi átlag 1 millió tonna tejegyenértékkel, ami - a vaj kivételével - nagyságrendileg 40\%-kal marad el az elmúlt évtized növekedésének ütemétól. A vaj globális kereskedelme az elmúlt évtizedben mért növekedéstől gyorsabb ütemben fog bővülni a várakozások szerint (o,1 millió tonna tejegyenertékről o,2 millió tonna körüli tejegyenértékre emelkedik az átlagos éves növekedés mértéke) (EUROPEAN COMMISSION, 2017).

Afrikában fóként a földrész északi és nyugati részein emelkedik a termelés. A tejtermelés és tejtermék importjának bővülésére főként a népességszám gyarapodása gyakorol hatást, elsősorban Nigériában, ahol az olajárak emelkedésével a jövedelem, ennek hatására pedig a tejtermékek behozatala is nő. Míg a Szaharától délre eső afrikai országok elsősorban zsíros tejport (fat filled milk powder, azaz FFMP, amely sovány tejpor, vagyis a hagyományos SMP és növényi zsír keveréke) importálnak, addig az észak-afrikai országokba irányuló sajt és vaj exportmennyisége több mint kétszeresére bővül majd az előrejelzések szerint (EUROPEAN COMMISSION, 2017).

Kína a világ legjelentősebb tejtermék importőre. Az ide irányuló kivitel továbbra is jelentősen emelkedik majd, évi átlagban mintegy 2\%-kal. A kínai államirányítás ötéves tervében ismerte el, hogy nem tudja biztosítani az önellátást tejtermékekból, így továbbra is behozatalra szorul. A kínai fogyasztók bizalma a külföldi termékek biztonságosságában rendkívül erős, emellett a kínai megavárosokban népszerü elektronikus kereskedelem könnyúvé teszi az importált tejtermékek háztartási beszerzését. Az előrejelzések szerint 2030-ra a kínai tejtermék-fogyasztás több mint ötöde importból származik. Az elmúlt években két komoly változást kell kiemelni a kínai tejtermék-piac tekintetében. Az importbővülés üteme az elmúlt tíz év mértékéhez képest kétharmadával csökkent a növekvő belföldi tejtermelés és a népességnövekedés csökkenő, évi o,2\%-os 
mértékének hatására. Az egykepolitika helyére lépő kétgyermekes családpolitika 2016-os bevezetésének számos pozitív hatása van, amelyek közül kiemelendő, hogy az egygyermekes családok 45\%-a második gyereket is vállalt, ami a jövőben ellensúlyozhatja a szülőképes korú nők számának apadását. Emellett megállapítható, hogy az importált tejtermékek megoszlásában emelkedett a nagyobb hozzáadott értéket képviselő tejtermékek, így különösen a sajt, a vaj és a tejszín aránya. Ennek oka, hogy Kína tejtermék-előállítói kapacitását meghaladják a helyi fogyasztói igények. Míg a WMP behozatala előreláthatólag nem nő tovább, addig a további feldolgozás céljából importált SMP volumene emelkedni fog. 2030-ra Kína sajtbehozatalának mennyisége - mintegy o,2 millió tonna terméksúlyban - megközelíti az USA hasonló értékét, különösen a mozzarella jellegű sajtok és a krémsajtok esetében. Ezzel párhuzamosan emelkedik majd Kínában a vajés tejszínimport is, amelynek oka a pékáruk előállításához szükséges alapanyagok iránti szükséglet. Az UHT tejek Kínába irányuló kivitele vissza fog esni. 2017 első felében a Kínába szállított folyékony tej mennyisége 10\%-kal lett kevesebb, míg a tejszín importja volumenben kétszeresére nőtt. Az UHT tejbehozatal visszaesése elsődlegesen a helyi tejtermelés növekvő versenyképességének köszönhető (EUROPEAN COMMISSION, 2017).
A tejalapú csecsemő tápszer (infant milk formula) importja a legjelentősebb Kínában, hiszen a 2016. évi mintegy 6 milliárd USD értékű tejtermék behozatalából 2,8 milliárd USD-t a csecsemő tápszer tett ki. A kínai import előreláthatóan a belföldi termelés és márkák erősödése ellenére továbbra is nőni fog. A további kelet-ázsiai országok felé mutató kivitel is emelkedik majd. Ki kell emelni a Dél-Koreába irányuló sajtexport mellett az Indonézia, Malajzia, a Fülöp-szigetek és Vietnam felé irányuló tejporkivitelt. A Közel-Kelet és Mexikó tejtermékbehozatala kisebb mértékben növekszik, míg Japán tejtermék-importja változatlan marad (EUROPEAN COMMISSION, 2017).

A tejtermékfogyasztás alapvető hajtóereje tehát Ázsiában, azon belül is Kínában van. Amennyiben historikus adatokon megvizsgáljuk, láthatjuk, hogy a sajtfogyasztás gyakorlatilag töretlenül ível felfelé, míg a sovány (SMP) és a teljes (WMP) tejpor fogyasztása 2005 környékén ugrott meg hirtelen Kína esetében. Habár mind az SMP, mind a WMP fogyasztása visszaesett 2014 után, az OECD-előrejelzések töretlen növekedését vetítik elő 2026-ig (1. ábra).

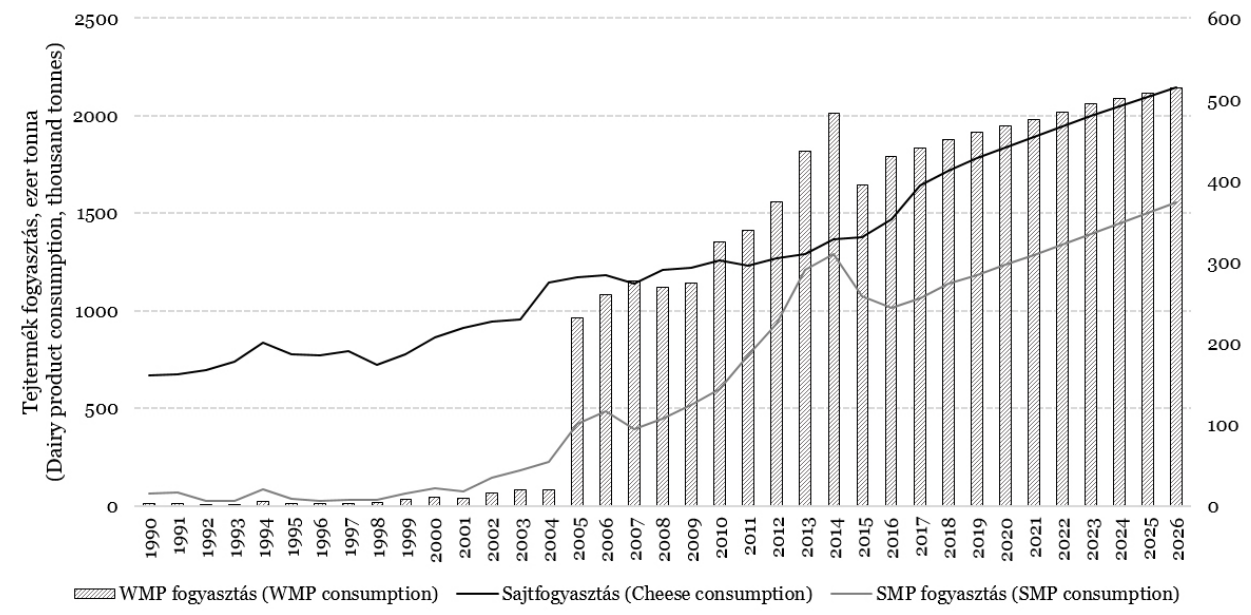

1. ÁBRA

A tejtermékfogyasztás alakulása Kínában 1990 és 2026 között (ezer tonna) (Dairy Product Consumption in China Between 1990 and 2026, Thousand Tons) Forrás (Source): OECD - FAO (2018) 
Ha az Oroszországot érintő kereskedelmi tilalmak 2019-ben is hatályban maradnak, akkor a tejtermékek oda irányuló kivitelének volumene aligha éri el az embargó bevezetését megelőző szintet. Oroszországban a visszaeső gazdasági növekedésből kifolyólag a tejtermékek fogyasztása is csökkent, miközben a belföldi tejtermelés kisebb mértékben erősödött az elmúlt évek során. Továbbá a hagyományosan erre a piacra szállító vállalatok az exportőr országokban részleges kompenzációban részesültek. Meg kell említeni, hogy Oroszországban az elmúlt évek során nőtt a tejhelyettesítő (analóg) termékek (és tejtermék-helyettesítő termékek) előállítása, például sajtot helyettesítő terméket készítenek tejfehérjéből növényi zsír hozzákeverésével, amely alacsonyabb áron érhető el, mint a valódi sajt. Nem meglepő, hogy 2016ban a belföldi sajtfogyasztás 16\%-kal csökkent 2013-hoz képest. A jövőben ugyanakkor a gazdaság erősödése és a rubel felértékelődése (az olajárak emelkedésével együtt) az exporttilalom eltörlésével növekvő sajtfogyasztáshoz vezethet. Az embargó eltörlését követően több év kell majd ahhoz, hogy Oroszország sajtimportja volumenét és értékét tekintve elérje az importtilalom bevezetését megelőző szintet, míg a vaj és a SMP importja (ez utóbbit a helyettesítő termékek gyártása során is felhasználják) várhatóan gyorsabban bővül (EUROPEAN COMMISSION, 2017).

A globális tejipart multinacionális cégek uralják, változatos székhelyekkel. 2018-ban a legjelentősebb tejipari vállalat a Nestlé volt. A svájci székhelyü vállalat 21,4 milliárd eurós forgalmat bonyolított le az elemzett időszakban. A francia Lactalis és a szintén francia Danone forgalma 17,7 és 15,5 milliárd euró volt ugyanebben az időszakban. A sort a Dairy Farmers of America (USA), a Fonterra (Új-Zéland), a FrieslandCampina (Hollandia), az Alra Foods (Dánia/Svédország) és a Saputo (Kanada) követi 9,6 és 13 milliárd euró közötti forgalommal. A TOP 20-ban egyébként fóként európai és amerikai vállalatok vannak. Ázsiából csak a Yili (Kína), a Mengniu (Kína) és a Meiji (Japán) képviselte magát. Főként Európában és az
USA-ban a leginkább jellemző, hogy a tejipari vállalatoknak kiemelten kell fókuszálni a helyi piacokra is, mivel a fogyasztók az átlagosnál jobban igénylik az olyan terméktényezóket, mint az eredetmegjelölés és a fenntarthatóság. Európában a tejipart viszont környezeti tényezők korlátozhatják (RABOBANK, 2018). Rövidtávon a termelők ki tudják védeni a tejárak ingadozásából fakadó visszásságokat, de közép- és hosszútávon a termelési költségnek mindig alacsonyabbnak kell lennie, mint az aktuális bevételek. Bár ez nyilvánvaló követelmény egy gazdaságos vállalkozással szemben, ez egyben azt is igényli, hogy alacsony tejárak esetén a termelőknek változtatniuk kell a menedzsment stratégiájukon (HEMME et al., 2014). Ez nagymértékben érinti a tejfeldolgozókkal való kapcsolatukat, továbbá az egymással való együttmúködésüket is. Az ágazati együttműködések különösen relevánsak lehetnek mind globálisan, mind európai uniós szinten a következő évtizedekben.

\section{ANYAg ÉS Módszertan - MATERIAL AND METHODS}

Összehasonlító és idősoros módszerek segítségével vizsgáltuk a tejágazat nemzetközi és hazai helyzetének alakulását. A tejágazat, a tejtermékek előállításának, kereskedelmének és koncentrációjának jövőbeli alakulása több ismert és elismert nemzetközi szervezet, valamint intézet és intézmény (OECD, FAO, USDA, Európai Bizottság stb.) előrejelzései alapján került elemzésre. A vizsgálatot nehezebbé teszi, hogy a különböző előrejelzések módszertana eltérő, alapjuk nem feltétlenül ugyanazokra a feltevésekre, nem ugyanarra az időszakra szól, továbbá bizonyos esetekben a gyüjtőfogalmak sem azonosan definiáltak. A tejágazat hazai kilátásainak elemzése során elsősorban az Európai Bizottság, a Központi Statisztikai Hivatal (KSH) és az Agrárgazdasági Kutató Intézet (AKI) adatbázisait és kutatásait használtuk. 


\section{EREDMÉNYek - Results}

\subsection{A globális szarvasmarha-állomány alakulása - The Changes of Global Cattle Herds}

2016-ban a világ szarvasmarha-állományának létszáma megközelítette az 1,5 milliárd egyedet, ami mintegy 50\%-os emelkedést jelent az 1970-ben mért értékhez viszonyítva. Az állomány 44\%-a öt országban vagy országcsoportban, Brazíliában, Indiában, az USA-ban, az EU-ban és Kínában található, a rangsor első 10 helyén álló ország (országcsoport) együttes részesedése megközelíti a 60\%-ot. Az 1,5 milliárd egyed túlnyomó többsége, 1,3-1,4 milliárd egyed a húshasznú szarvasmarhák csoportjába tartozik. Ennek oka, hogy például Kínában, Indiában és számos további fejlődő országban a kettős hasznosítású típusba sorolt, de főként hústermelési céllal tartott szarvasmarhát tekinthetjük jellemzőnek (FAO, 2017). A jövőben mind a tej-, mind a húshasznú állomány további bővítési lehetőségeit jelentősen korlátozza majd a rendelkezésre álló földterület és víz mennyisége, vagyis a bővülő fogyasztási igényeket elsősorban a hozamok javulásával kell majd elérni (HARANGI-RÁKOS et al., 2016).

A FAO becslése alapján 2016-ban a tejhasznú tehénállomány 273,7 millió egyedet számlált globális viszonylatban. A világ tejhasznú tehénállományának 60\%-át 15 országban és országcsoportban tartják. Az Indiában található, 48 millió egyedból álló tejelő állomány a legnagyobb létszámú a világon, ezt az EU és Brazília állományai követik 23,6, illetve 19,6 millió egyeddel. Indiában - vallási okokból - elvileg nem engedélyezett a tehénvágás, ennek ellenére mégis emelkedik az évi marhahús-előállítás, hiszen a bivalyhúst is ide sorolják és a tejhasznú selejtbivaly vágása nem tiltott, de mindezzel párhuzamosan évról évre emelkedik a tiltott tehénvágások száma is. Ennek köszönhetően Indiában az utóbbi évek során jelentős mértékben nőtt a „marha- és bivalyhús” exportja is (FAO, 2017).

\subsection{A tejtermelés kilátásai az EU-ban - The Prospects of Dairy Production in the EU}

1984 és 2015 között az EU tejágazatának müködését a tejkvóták befolyásolták. Ezek 1984es beveztésének célja a túltermelés problémájának kezelése volt. A kvótarendszer 2015-ben járt le. Habár Magyarország a kvótáját sosem érte el, a kvóta ennek ellenére is szabályzó erővel bírt, mivel a hatékonyabb tagállamokat ettől függetlenül korlátozta.

A világszintű tejágazat ma 7,6 milliárd fogyasztót lát el különböző tejtermékekkel, emellett mintegy 1 milliárd főnek biztosít megélhetést a tej- és tejtermék-ellátási láncban végzett munka (IFCN, 2016). A világ tejtermelése 2016-ban megközelítette a 820 millió tonnát, amennyiben nem csak a tehéntejet vesszük figyelembe, ami 1\%-nyi növekedést jelent az előző évben elért teljesítményhez képest (AKI, 2016). A fejlődő országok tejtermelésének növekedésére mindenekelőtt a kínai importigény gyakorol hatást. A következő tíz évben a mai 2,0\%-os éves növekedési ütem előreláthatólag évi 1,8\%-ra csökken majd, de egy évtized alatt még így is $23 \%$-kal fog nőni a tejtermelés. A fejlődő országok esetében a termelés bővülését segíti a fajlagos tejhozamok növekedése, a takarmányárak mérséklődése és az emelkedő átlagos állományméret. Ehhez képest a fejlett országok körében a tejtermelés várhatóan 1\%kal fog emelkedni évente, amelynek forrása kizárólag a fajlagos hozamok további emelkedése lesz, hiszen a tejelő állomány létszáma várhatóan kisebb mértékben csökkenni fog. A globális termelés emelkedésének 73\%-át a fejlődő országok adják majd, amelyek közül kiemelkedik India és Pakisztán (AKI, 2016; OECD - FAO, 2016). A tejtermékek forgalmának gyarapodása elsősorban a friss tejtermékek piacán jelentkezik majd (évi 2,9\% emelkedés a fejlődő országokban), mindenekelőtt belpiaci fogyasztási céllal. A fóbb tejtermékek előállítása a tejtermeléshez hasonló ütemben bővül majd az előrejelzések alapján. Az Indiában és Pakisztánban jelentkező termelési többletet és az előállított tejet és tejtermékeket túlnyomó 
részben belföldön, friss tejtermék formában fogyasztják majd, vagyis a fogyasztási szerkezetben nem várható a feldolgozott termékek arányának emelkedése (OECD - FAO, 2016).

Az EU lesz felelős a globális tejtermék-kereskedelem növekményének 30\%-áért. Az EU exportja a tejsavóport (whey powder) és a friss tejtermékeket is beleértve évente átlagosan 400 ezer tonna tejegyenértékkel nő majd az előrejelzések szerint, főként a sajt és az SMP növekvő kivitelének köszönhetően. Évi mintegy 900 ezer tonnával több tejjel lesz kielégíthető az EU növekvő belső piaci kereslete. Az EU belső piacán mindenek előtt a sajtok és egyéb tejtermékek, így különösen a tejalapú desszertek, a zsíros tejpor, a tejalapú csecsemőtápszerek, továbbá a fehérje- és tejsavó-koncentrátumok iránti kereslet fog emelkedni. Ezzel ellentétben a folyadéktej iránti fogyasztói igény további csökkenése várható. Ennek oka - egyebek mellett - a közösségi médiában a felnőttek alacsonyabb tejfogyasztását célzó kampányok megjelenése, amelyek hatására a folyadéktej fogyasztása csökken. Ehhez hozzájárul a laktózintolarenciában szenvedők magasabb száma is. A feldolgozott termékek előállítása nagyobb jelentőséggel bír majd, ennek hatására emelkedni fog a fogyasztás sajtból (ennek oka a pizzák, a félkész- és késztermékek fogyasztásának növekedése), sovány tejporból és vajból is. Ez utóbbi elsődlegesen a pékáruk és sütemények iránt mutatkozó kereslet emelkedésének köszönhető (EUROPEAN COMMISSION, 2017). A magasabb jövedelemmel rendelkező vásárlók, közülük is elsősorban a 40 évnél fiatalabb nők akár átlagosan 5-15\%-kal magasabb kiskereskedelmi vételárat is hajlandóak voltak fizetni a különböző tejtermékekért, amennyiben biztosak voltak az előállításukhoz felhasznált alapanyag eredetében (SZABÓ-SZENTGRÓ-
TI et al., 2017), vagyis van kereslet a speciális igényeket célzó tejtermékek vásárlására, csak az előállítás során kiemelt figyelmet kell szentelni a fogyasztói igényekre. A fogyasztók figyelmét több kommunikációs csatornán át is felhívhatjuk az elérhető lehetőségekre. Ehhez kiváló eszközt jelent - például az imént említett, Y generációhoz tartozó fogyasztói csoport esetében - az online kampányok és közösségi médiakampányok indítása. Arra ugyanakkor figyelmet kell fordítani, hogy a közösségi médiumok egy része nem számít hiteles forrásnak a fogyasztók szemében, így az egyébként nagy hitelességgel rendelkező szereplők (például ágazati terméktanácsok, kutatóhelyek, egyetemek) saját közösségi médiaplatformjaikon közzétett kutatási eredmények publikálásával támogathatják a tej- és tejtermék-fogyasztás népszerüsítését (FEHÉR - SZAKÁLY, 2013).

2016-ban Németország tejelőszarvasmarha-állománya mintegy 4,2 millió egyed volt. Franciaországban ezzel egyidejúleg 3,6 millió tejelő szarvasmarhát tartottak, a Lengyelországban tartott létszám pedig még mindig meghaladja a 2 millió egyedet. Az Egyesült Királyságban mért állománynagyság 1,9 millió egyed körül alakult. Magyarországon 244 ezer tejelő szarvasmarhát tartottak ugyanezen évben, vagyis 2010-hez képest emelkedni tudott az állomány létszáma. 2010-hez mérve Németországban a tejelő tehénállomány 1\%-nyit, az Egyesült Királyság területén 3\%-nyit, Hollandiában 18\%-nyit, míg itthon 2\%-nyit gyarapodott. Ezzel egyidőben a francia állomány 2\%kal, a lengyel pedig 16\%-kal zsugorodott (2. ábra). Az EU 28 tagállamában az elmúlt évek során érdemben nem változott a tejelö tehenek száma, ami 23,2 és 23,3 millió egyed között alakult. 


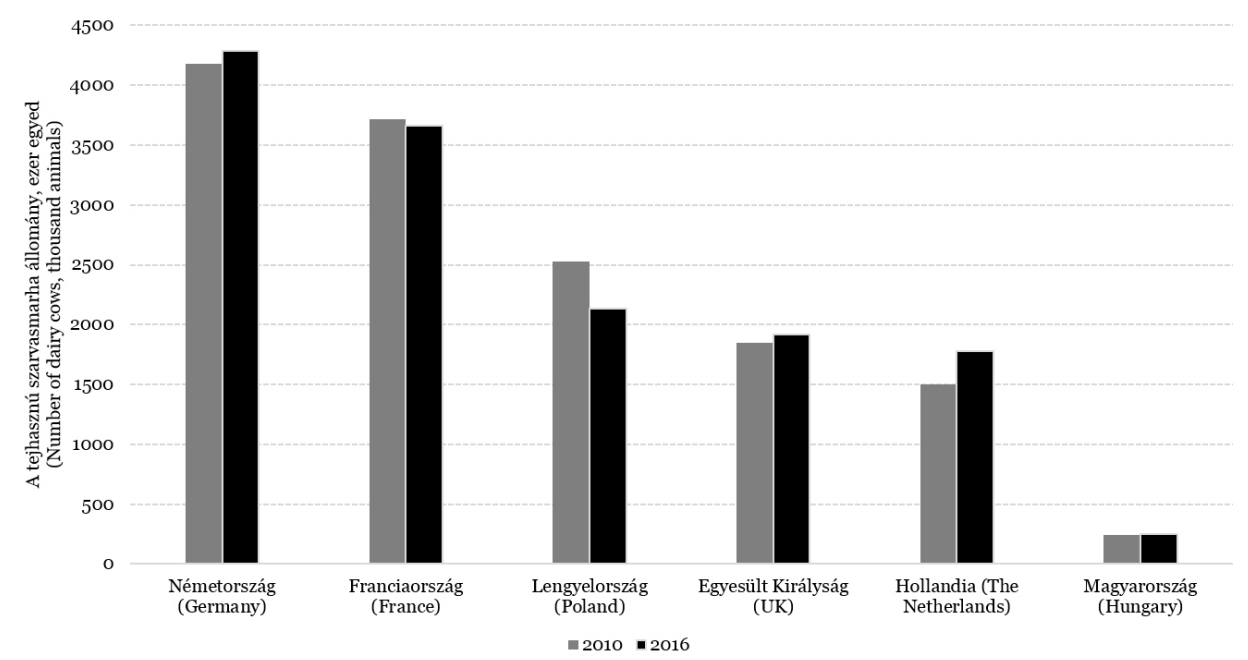

2. ÁBRA

FIG. 2

A tejhasznú szarvasmarha-állomány alakulása az EU egyes tagországaiban (2010 és 2016) (The Changes in Number of Dairy Cattles in the EU Member States Between 2010 and 2016) Forrás (Source): EUROSTAT (2018)

Az MMO (2018) adatközlése szerint az egy tehénre jutó tejhozam $7900 \mathrm{~kg}$ volt 2016-ban Magyarországon. Hasonló hozamértékeket mutat Németország (7 $700 \mathrm{~kg}$ ), Csehország (8 $300 \mathrm{~kg})$, az Egyesült Királyság (7 $900 \mathrm{~kg}$ ) és Hollandia is $(7800 \mathrm{~kg})$. A legjelentősebb hozamokat Spanyolországban, Dániában, Svédországban, Finnországban és Észtországban mérték. Ezen országok esetén az egy tehénre eső évi tejhozam átlaga $8700 \mathrm{~kg}$ (Finnország) és 9 600 kg (Dánia) között változott évente. Ehhez viszonyítva egyes tagországokban jelentősen alacsonyabb teljesítményt mértek, így például Romániában az egy tehénre jutó tejhozam mindössze $3300 \mathrm{~kg}$ volt 2016-ban. Az EU-28 átlaga tehenenként évi $6900 \mathrm{~kg}$, míg az EU-15 átlaga évi $7300 \mathrm{~kg}$ volt egy tehénre vetítve.

$\mathrm{Az}$ EU tagállamokban a feldolgozók által felvásárolt tej mennyisége 2016-ban meghaladta a 153 millió tonnát. Ez az érték nem teljesen egyezik meg a termelők össztermelésével, mivel az az érték tartalmazza a termelőegységben felhasznált tej mellett a házi fogyasztás és a közvetlen értékesítés során hasznosuló menynyiségeket is. Az EU legnagyobb tejtermelője Németország volt, ahol emellett az uniós feldolgozók által felvásárolt tej 21\%-át, 32 millió tonnát fel is dolgoztak. Franciaország részesedése elérte a 16\%-ot (ez 24,5 millió tonnának felel meg), míg az Egyesült Királyság 10\%-os, 14,6 millió tonnával egyenlő értéket mondhatott magáénak. Ezeket a tagállamokat sorrendben Hollandia, Olaszország és Lengyelország követte $7 \%$ és 10\% közötti részesedéssel. Magyarország a rangsor 19. helyét érte el, részesedése mindössze 1\%-os volt (3. ábra). 


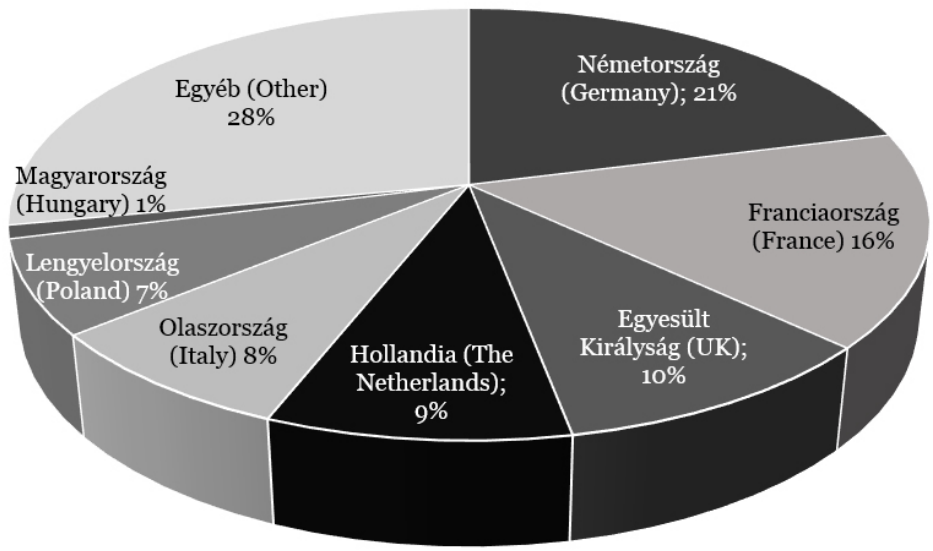

3. ÁBRA

A feldolgozók által begyưjiött tejmennyiség alakulása

az EU egyes tagországaiban (2010 és 2016)

(The Quantity of Milk Collected by Dairy Processors in EU Member States (2010 and 2016))

Forrás (Source): EUROSTAT (2018)

\subsection{A tej és tejtermékek nemzetközi kereskedelme - The International Trade of Milk and Dairy Products}

A mezőgazdasági termelés mindössze $10 \%$-a kerül a nemzetközi kereskedelembe. Ez az általános arány a tejtermékek piaca esetén is igaz. Az OECD - FAO (2018) adatközlése szerint a nemzetközi kereskedelembe kerülő tejtermékek több mint négyötöde fejlődő országokból származik. Ezen országok esetében a következő évtized során 21\%-kal emelkedik a kivitel. Az EU kivételével a legfontosabb exportőr országok kivitele akár vissza is eshet, hiszen a friss tejtermékek iránt jelentősebb kereslet mérhető, mint a feldolgozott termékek esetében. A friss tejtermékeket tárolása és szállítása ugyanakkor nehezebb és körülményesebb, így ebben a termékcsoportban nem jellemző a nagy távolságra történő szállítással járó kivitel. A behozatal ehhez képest sokkal kevésbé koncentrált, noha a tejtermékek importjának mintegy felén az ázsiai országok osztoznak.

2016-ban a legjelentősebb vajexportőrök Új-Zéland, az EU, Fehéroroszország és Ausztrália voltak, amelyek kivitele sorrendben 450 ezer, 204 ezer, 70 ezer és 26 ezer tonna volt a vizsgált évben. A teljes tejpor exportjában Új-Zéland és az EU volt a két legjelentősebb szereplő 1,1 millió és 356 ezer tonnányi export- mennyiséggel. Mellettük meg kell még említeni Uruguay és Argentína kivitelét is. A sajt esetében az EU (737 ezer tonna), Új-Zéland (318 ezer tonna), az USA (26o ezer tonna) és Fehéroroszország (189 ezer tonna) volt a legjelentősebb exportpiaci szereplő. A sovány tejpor exportját túlnyomó többségében az USA, az EU, Új-Zéland és Ausztrália bonyolította le. Országonként, országcsoportonként vizsgálva látható, hogy az USA és az EU 500-550 ezer tonna kivitelt bonyolított (MMO, 2018). Fehéroroszország exportőri pozíciójára jótékony hatást gyakorolt az oroszországi embargó, hiszen ezen a külpiacon növelni tudta piaci részesedését.

2016-ban sajtbehozatal tekintetében a világ legjelentősebb piacait Oroszország, Japán, az USA és Dél-Korea jelentették. Utóbbi kivételével az Oroszországba, az USA-ba és a Japánba irányuló importmennyiség növekedett, sorrendben 209 ezer tonnáról 223 ezer tonnára, 249 ezer tonnáról 258 ezer tonnára és 200 ezer tonnáról 205 ezer tonnára. Dél-Korea esetén az import gyakorlatilag nem változott, 110 ezer tonna körüli értéket mutat. A vaj legfontosabb importôre Oroszország volt 105 ezer tonna mennyiséggel, amit Kína (82 ezer tonna), Mexikó (52 ezer tonna) és az USA (47 ezer tonna) követett a vizsgált évben. A sovány tejpor behozatalában Kína, Algéria, Mexikó és Oroszország volt a legfontosabb szereplő, bár Kína és 
Algéria importja visszaesett. A teljes tejpor esetében a legnagyobb importőr országok Kína, Algéria, Brazília és Hongkong (Kína) voltak (MMO, 2018).

\subsection{A hazai szarvasmarha-ágazat helyzete - The Situation of Hungarian Cattle Sector}

A 4. ábra hazánk szarvasmarha-állományának alakulását szemlélteti 2004 és 2017 között. A szarvasmarha létszáma 2004-ben 723 ezer egyed volt, mely a következő 5 évben tovább csökkent. A legalacsonyabb szarvasmarha-lét- szám (682 ezer egyed) 2010-ben volt, de 2012 óta a szarvasmarha- és tehénlétszám növekedése figyelhető meg (KSH, 2018a). A szarvasmarha-állomány 2018. június 1-jén 880 ezer volt, számuk egy év alatt 16 ezerrel nőtt. Az elmúlt öt évben az állomány bővülése megközelítette a 117 ezret (15\%-ot). A tehénállomány (397 ezer) egy év alatt 4, öt év alatt összességében 61 ezerrel gyarapodott. A szarvasmarha-állomány 59\%-át gazdasági szervezetek, 41\%-át egyéni gazdaságok tartották. A gazdasági szervezetek állománya nem változott, az egyéni gazdaságoké 15 ezerrel bővült az egy évvel korábbihoz képest (KSH, 2018a).

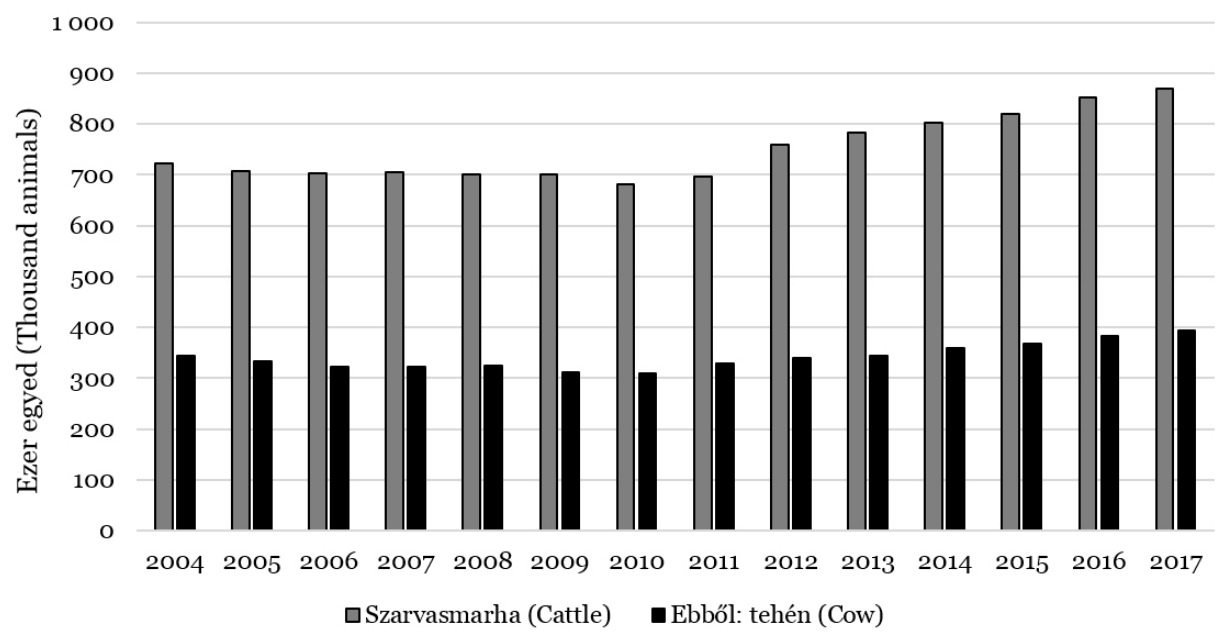

4. ÁBRA

Magyarország szarvasmarha-állománya 2004-2017 között (ezer egyed)

FIG. 4 (The Cattle Herds in Hungary Between 2004 and 2017 (thousand animals))

Forrás (Source): KSH (2018a) 
A tehenek 54\%-a tejhasznú, 38\%-a húshasznú, valamint 8\%-a kettős hasznosítású (5. ábra). A tejhasznú tehénállomány $81 \%$-a gazdasági társaságok tulajdonában van, csupán 19\%-ot képviselnek az egyéni gazdaságok. A tejhasznú tehénállomány 2017-ben a gazdasági társaságoknál 3\%-kal csökkent, az egyéni gazdaságoknál 12\%-kal nőtt az előző évhez (2016. június) képest (KSH, 2018a). A tejhasznú és kettőshasznosítású tehenek száma együttesen az elmúlt egy év során a gazdasági szervezeteknél közel 1 ezerrel nőtt, az egyéni gazdaságoknál 2 ezerrel csökkent.

A hazai tejtermelő gazdaságok száma folyamatos csökkenést mutat az elmúlt 10 évben. 2016-ban a tejtermelő gazdaságok száma 442re csökkent (6. ábra) (KSH, 2018a). Ennek oka, hogy az Európai Unió számos új környezetvédelmi és állategészségügyi előírást léptetett hatályba a 2004-es csatlakozást követően, melyeknek számos telep nem tudott megfelelni, így kénytelen volt felszámolni a gazdaságot vagy a tejelő állományt.

Magyarország tejtermelése 2016-ban megközelítőleg 1,9 milliárd liter volt, szerény mértékben csökkent az előző évhez képest (7. ábra). Az évi tejtermelés a 2004-2016 közötti időszakban összességében stagnált. Ezzel szemben az egy tehénre jutó tejtermelés folyamatos növekedése figyelhető meg, mely a 2014. évi 7248 l/tehén/év értékről 7562 l/tehén/év értékre emelkedett (KSH, 2018b).

Magyarországon a tej és tejtermékek fogyasztása (évi 179 liter/fö) napjainkban elsősorban jövedelmi kérdés. A közép-kelet-európai uniós tagországokhoz képest is alacsony a fogyasztás, hiszen még Romániában és Lengyelországban is $\mathbf{2 0 0 - 2 6 0 ~ k g / f o ̈ / e ́ v ~ t e j t e r m e ́ k e t ~}$ fogyasztanak tejegyenértékben kifejezve. A magyar folyadéktej- és sajtfogyasztás EU tagországok átlagának egyharmadát teszi ki (KOVÁCS, 2016). Az alacsony jövedelmek és a magas árérzékenység miatt a kereslet határozza meg a tejpiac árazási mechanizmusát. Ennek ellenére a hazai tejmarketing még nem kiforrott, a tejpiaci szereplők pedig alig élnek a modern kor adta marketinlehetőségekkel (FEHÉR - SZAKÁLY, 2018, FEHÉR - SZAKÁLY, 2010).

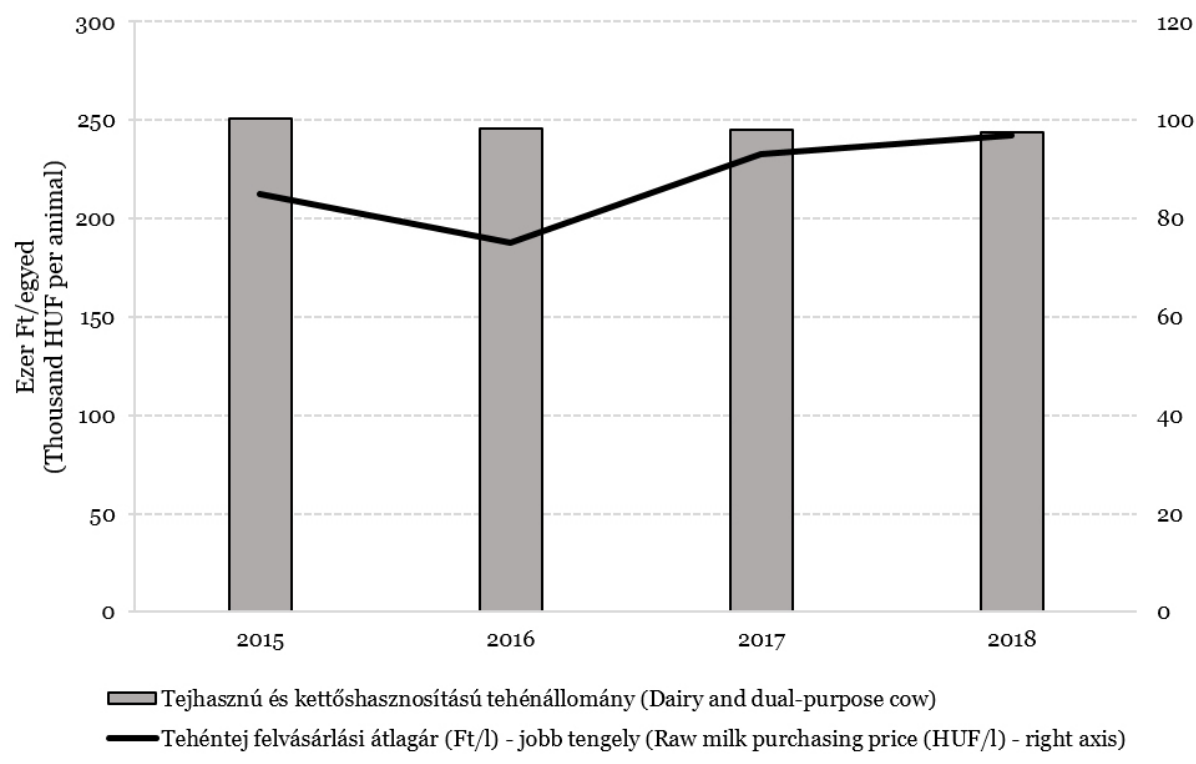

5. ÁBRA

FIG. 5

A tejhasznú és kettőshasznosítású tehénállomány és a tehéntej felvásárlási átlagárának alakulása (ezer egyed, Ft/l)

(Milk Producing and the Dual-purpose Herd Size and the Development of Purchase Price of Milk (thousand animals, HUF/l)) 


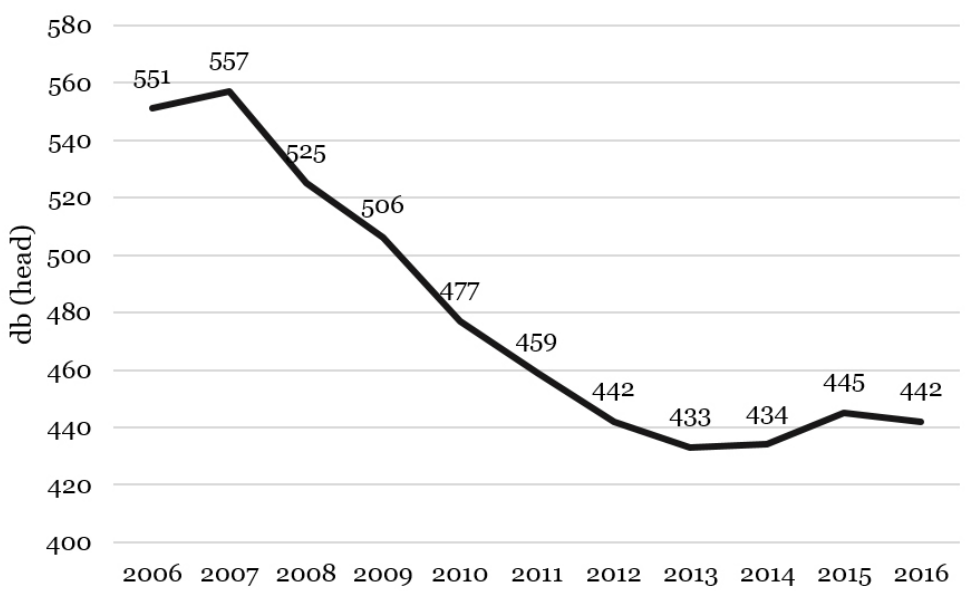

6. ÁBRA

A hazai tejtermeló gazdasági szervezetek száma (db)

FIG. 6 (Number of Milk Producing Companies in Hungary (Head))

Forrás (Source): KSH (2018a)

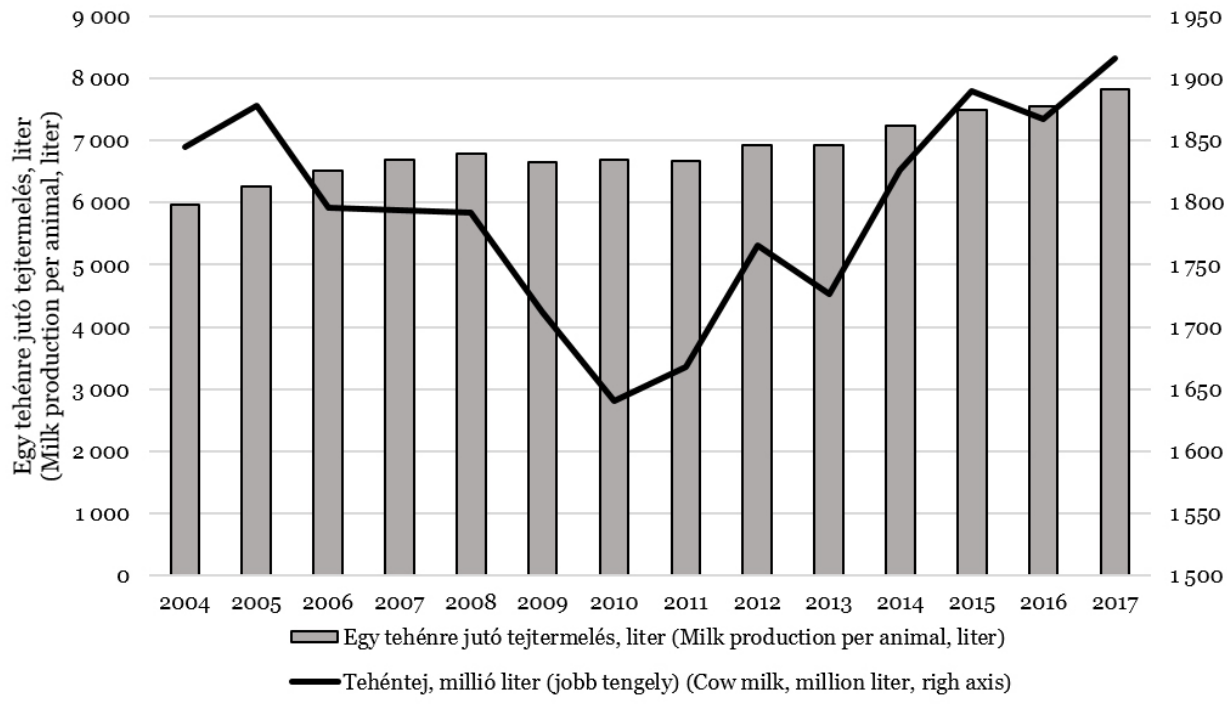

7. ÁBRA

Az összes és az egy tehénre jutó tejtermelés hazánkban 2004-2016 között (liter)

FIG. 7

(Total Milk Production and Milk Production Per Cow in Hungary

Forrás (Source): KSH (2018b)

Between 2004 and 2016 (liter)) 


\subsection{A tejipar koncentrációja - \\ The Concentration of Dairy Industry}

A folyadéktejek piacának értékesítése elérte a 135,4 milliárd Ft-ot 2017-ben. A folyadéktejek piacán az Alföld Tej Értékesítő és Beszerző Kft.-nek volt a legmagasabb részesedése kiskereskedelmi értéken számolva. 2017-ben körülbelül 26\%-os részesedéssel a piac egynegyedét lefedte, amelyet fóként a friss tej és a tartós tej szegmensekben látható erôs és stabil jelenlétének köszönhet (8. ábra). Ôt követte a Sole-Mizo Zrt. 10,3\%-kal. A FrieslandCampina Hungária Zrt. 6,5\%-kal a harmadik volt a sorban, de nem sokkal maradtak el tóle az olyan jól ismert hazai áruházláncok, mint a TescoGlobál Áruházak Zrt., a Spar Magyarország Kiskereskedelmi Kft. vagy a CBA Kereskedelmi Kft. A koncentráció foka magas a folyadéktejek piacán, hisz összesen 7 piaci szereplő a 63,6\%át lefedi (EMIS, 2018b).

A sajt talán a legjelentősebb feldolgozott terméknek számít a tejtermékek piacán. Magyarországon a legnagyobb részesedése a Pannontej Zrt.-nek van (megközelítőleg 20\%) kereskedelmi értéken számolva. A Tolnatej Zrt. szintén jelentősebb piaci szereplő 16,4\%-os piaci részesedéssel, melyet a Sole-Mizo Zrt.-t követ 8,3\%-os piaci részesedésével (9. ábra). A piac többi szereplője jellemzően kisebb részesedéssel bír az első három vállalathoz képest és 7\%-os részesedés alatt maradnak. A piac első három szereplője a teljes piac 44,5\%-át lefedi részesedés alapján, míg az első hét szereplő 62,6\%-kal bír (EMIS, 2018c).

A vaj és a margarin egymás helyettesítő termékei, 62,2 milliárd Ft-os piacot jelentettek Magyarországon 2017-ben. Az utóbbi években a vaj szerepe csökkent a belföldi fogyasztásban, mivel a margarin egy olcsóbb és gyakran egészségesebb termékként feltüntetett alternatívát kínál. A legnagyobb magyarországi kereskedelmi részesedéssel az Unilever Magyarország Kft. rendelkezett 2017-ben és 45\%-os részesedésével uralta is a piacot (10. ábra). Az őt követő piaci szereplők között a részesedés $6 \%$ alatt maradt. A vaj és a margarin piaca még erősebben koncentrált, mint a folyadéktej vagy a sajtpiac. Az első három szereplő a piac több mint felét lefedte (56\%) míg az első hét szereplő a piac több mint kétharmadát (70,4\%-át) uralta (EMIS, 2018d).

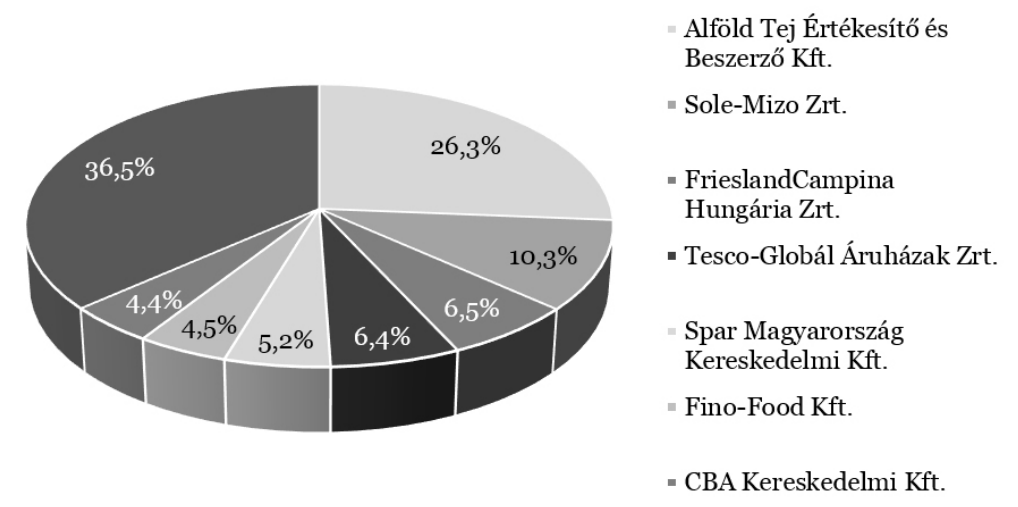

8. ÁBRA

A vállalati részesedések a folyadéktej piacán Magyarországon 2017-ben

FIG. 8 (Kereskedelmi érték, kereskedelmi értékesítési árakon számolva, \%) (Company Shares on the Liquid Milk Market in Hungary in 2017 Value of Trade, Based on the Commercial Sales Price, \%)

Forrás (Source): EMIS (2018b) 


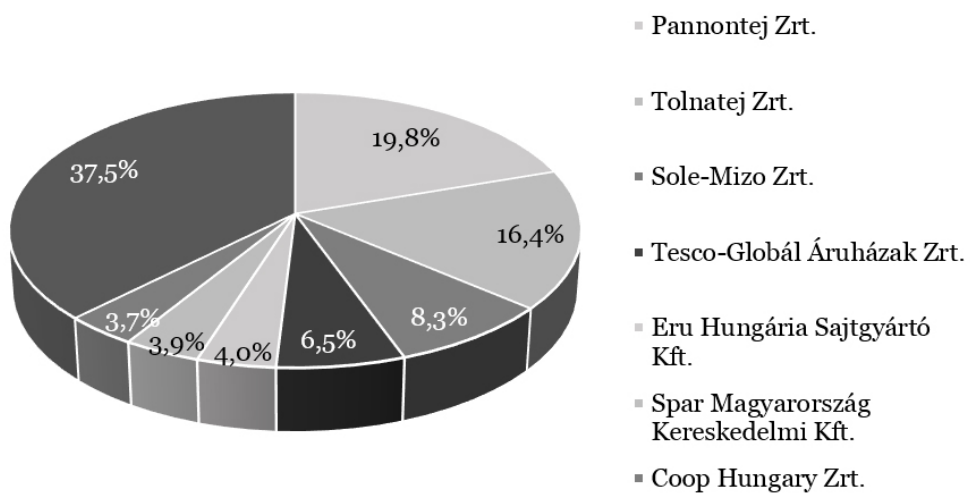

9. ÁBRA

A vállalati részesedések a sajtok piacán Magyarországon 2017-ben

FIG. 9 (Kereskedelmi érték, kereskedelmi értékesítési árakon számolva, \%) (Company Shares on the Cheese Market in Hungary in 2017 Value of Trade, Based on the Commercial Sales Price, \%)

Forrás (Source): EMIS (2018c)

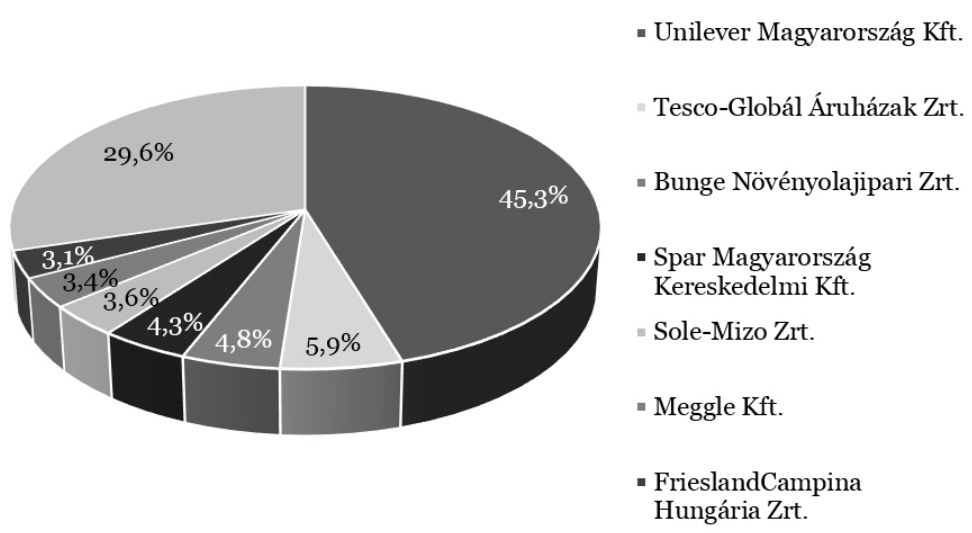

1O. ÁBRA

A vállalati részesedések a vaj és a margarin piacán Magyarországon 2017-ben

(Kereskedelmi érték, kereskedelmi értékesítési árakon számolva, \%)

(Company Shares on the Butter and Margarine Market in Hungary in 2017Value of Trade, Based on the Commercial Sales Price, \%)

Forrás (Source): EMIS (2018d)

FIG. 10 
A tejtermékek kereslete során érdemes a magyarországi keresletet összehasonlítani az EU vezető tejpiaci szereplőjével, Németországgal. A németországi tejtermékek teljes kereslete közel 28,5 milliárd dollár volt 2017-ben, míg a magyarországi ennek töredéke, 1,2 milliárd dollár. A kereslet terméktípus szerinti megoszlásában jelentős különbségeket lehet felfedezni. A hazai kereslet szerkezetében domináns a sajt kereslete közel 36\%-kal és a tej és tejszín kereslete közel 26\%-kal. Emellett jelentős kategória még a jégkrém szegmens 20\%-os részesedéssel. Ezzel szemben a németországi tejtermék-kereslet felét adja a sajt, továbbá közel 20\%-ot a tej és tejszín. A kereslet mennyisége egyébként 963 ezer tonna volt 2017-ben Magyarországon, míg Németországban 18 millió tonna. Magyarországon és Németországban is az egyéb sajttípusok kategóriába sorolt sajtok részesedése a legmagasabb. Egy főre vetítve USA dollárban kifejezve a különbség kétszeres a tej és tejszín kategóriában Németország javára. A sajt esetében ugyanez a különbség már négyszeres. Egyedül a jégkrém kategória az, ahol magasabb az egy főre jutó kereslet Magyarországon, egyébként a németországi egy főre jutó adatok mindig jelentősen magasabbak (1. táblázat).

1. TÁBLÁZAT

TABLE 1

A tejtermékek kereslete értékben kifejezve Németországban és Magyarországon típus szerint 2017-ben (millió US dollár és US dollár per fó)

(The Demand of Dairy Products in Value in Germany and in Hungary by Types in 2017 in Million USD and in USD per Capita)

\begin{tabular}{|c|c|c|c|c|c|c|}
\hline \multirow[b]{2}{*}{ Kategóriák (Categories) } & \multicolumn{3}{|c|}{ Németország (Germany) } & \multicolumn{3}{|c|}{ Magyarország (Hungary) } \\
\hline & $\begin{array}{l}\text { Millió US } \\
\text { dollár } \\
\text { (Million } \\
\text { USD) }\end{array}$ & $\begin{array}{c}\text { US dollár/ } \\
\text { fó (USD/ } \\
\text { capita) }\end{array}$ & $\%$ & $\begin{array}{l}\text { Millió US } \\
\text { dollár } \\
\text { (Million } \\
\text { USD) }\end{array}$ & $\begin{array}{c}\text { US dollár/ } \\
\text { fö (USD/ } \\
\text { capita) }\end{array}$ & $\%$ \\
\hline $\begin{array}{l}\text { Tej és tejszín (Milk and } \\
\text { cream) }\end{array}$ & 5218,80 & 63,55 & 18,32 & 298,5 & 30,70 & 25,43 \\
\hline Tejpor (Milk in powder) & 2309,00 & 28,11 & 8,10 & 21,8 & 2,24 & 1,86 \\
\hline Sajt (Cheese) & 13631,60 & 166,00 & 47,84 & 418,1 & 43,01 & 35,61 \\
\hline Vaj (Butter) & 1950,80 & 23,75 & 6,85 & 45,8 & 4,71 & 3,90 \\
\hline Jégkrém (Ice cream) & 1280,30 & 15,59 & 4,49 & 227,7 & 23,42 & 19,40 \\
\hline Joghurt (Yoghurt) & 1240,20 & 15,10 & 4,35 & 46,1 & 4,74 & 3,93 \\
\hline Egyéb (Other) & 2862,80 & 34,86 & 10,05 & 115,3 & 11,86 & 9,82 \\
\hline Összesen (Total) & 28492,10 & 346,98 & 100 & 1174 & 120,76 & 100 \\
\hline
\end{tabular}

A népességszámot a World Population Review alapján határoztuk meg

(Population was determined based on World Population Review) (82 114224 és 9721559 fö (capita). ${ }^{1}$

Forrás (Source): GLOBAL RESEARCH \& DATA SERVICES (2018a) és (2018b)

A cégek árbevétel alapján történő rangsorolása esetén szembetűnő, hogy a tejpiacot néhány cég dominálja. A NAICS iparági osztályozása alapján a Tejtermékek gyártása (3115) kategóriában az első 35 vállalatot tekintve az árbevétel értéke 2017-ben 5 millió Ft (Ökotej Zrt.) és 62,3 milliárd Ft (SOLE-MiZo Zrt.) között mozgott mint két szélsőérték. 2017-ben egyébként 37 vállalatot rögzített az EMIS cégadatbázis mint iparágban tevékenykedő vállalat, összesen 308,6 milliárd Ft-os nettó árbevétellel. A legnagyobb piaci részesedést árbevétel alapján a SOLE-MiZo Zrt. tudta elérni, 67,3 milliárd Ft-os árbevétele közel 22\%-os piaci részesedést eredményezett. Nem sokkal lemaradva követte az Alföldi Tej Kft. 17,4\%-kal, amelyhez 53,6 milliárd Ft-os árbevétel tartozott. Azonos piaci részesedéssel rendelkezett a Kőröstej Kft., a Tolnatej Zrt. és a FrieslandCampina Hungária Zrt. A cégek árbevétele

${ }^{1}$ http://worldpopulationreview.com/countries/germany-population/; http://worldpopulationreview.com/countries/hungary-population/ 
30-31 milliárd Ft volt, körülbelül 10\%-os piaci részesedés mellett fejenként. Az első 20 cég árbevétele haladta meg az 1 milliárd Ft-os határt. Jól látható, hogy a piac erősen koncentrált, mivel árbevétel alapján az első három cég a piac felét, az első öt cég a piac 70\%-át, míg az első 10 cég a piac 88\%-át lefedi (11. ábra).

Teljes mintás hozzáférésünk a 2016-os értékesítési adatokhoz volt, így ezek alapján lehetett meghatározni a jövedelmek koncentrálódását. A minta 43 tejfeldolgozót tartalmazott, ahol az utolsó helyen lévő vállalatok piaci részesedése már elenyészően kicsi volt. A Gini-index 0,7 körül alakul a mintában, amely azt mutatja, hogy a jövedelmek erősen koncentrálódnak, azaz kevés vállalat bonyo- lítja le az értékesítések nagy részét (o értékű Gini-index teljes egyenlőséget, míg 1 értékű Gini-index teljes koncentrációt mutatna). Ez nem meglepő annak fényében, hogy az első három vállalat átlagosan a piac felét lefedi. A 12. ábra a minta Lorenz-görbéjét szemlélteti. Értelmezése a következő: a vállalatok p*100\%-a birtokolja a jövedelmek L(p)*100\%-át. Azaz a vállalatok átlagosan $80 \%$-a a teljes piaci értékesítés mindössze $20 \%$-át fedi le, míg a vállalatok fennmaradó 20\%-a az értékesítések fennmaradó 80\%-át. Ennek fényében nem meglepő az, hogy általánosan elterjedt az a nézet, hogy a feldolgozók alkufölényt élveznek a termelőkkel szemben.

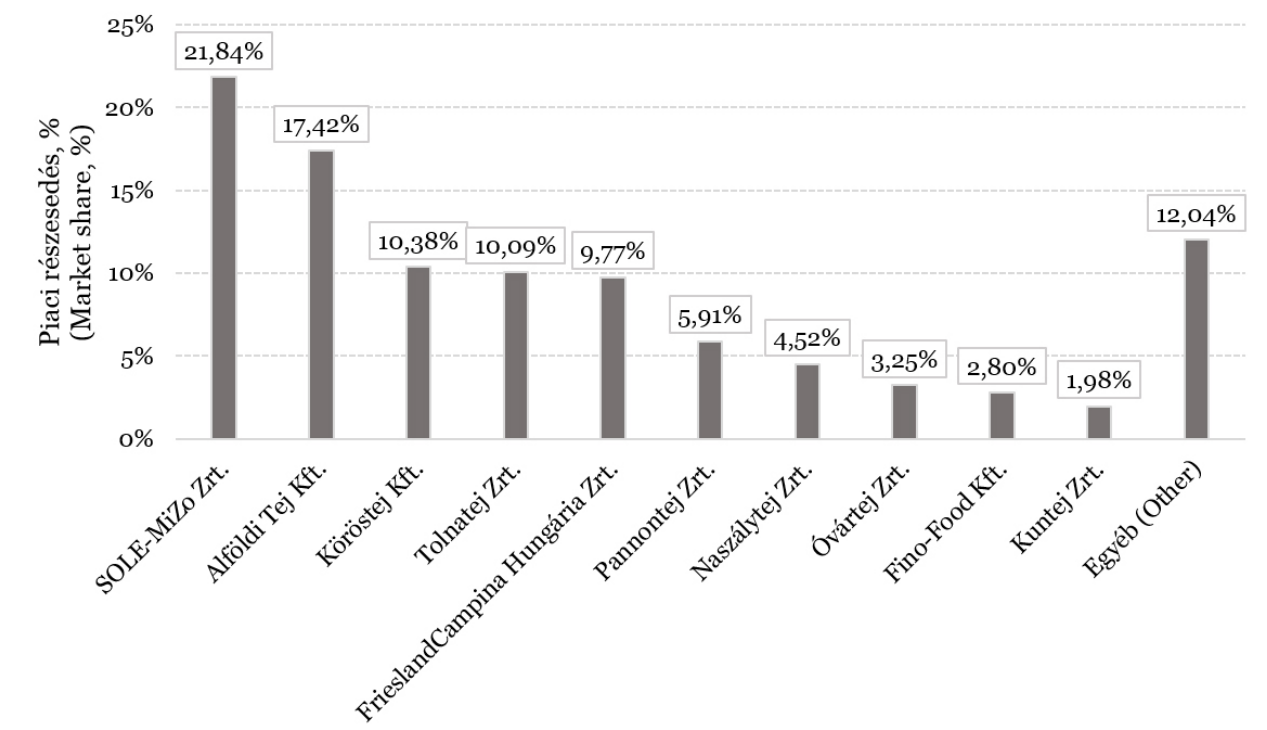

11. ÁBRA

A tíz legjelentősebb hazai tejpiaci szereplő árbevétel-részesedés alapján rangsorolva 2017-ben

(The Rank of the Ten most Important Actors of the Hungarian Dairy Market by Revenue Shares in 2017)

Forrás (Source): EMIS (2018a) 


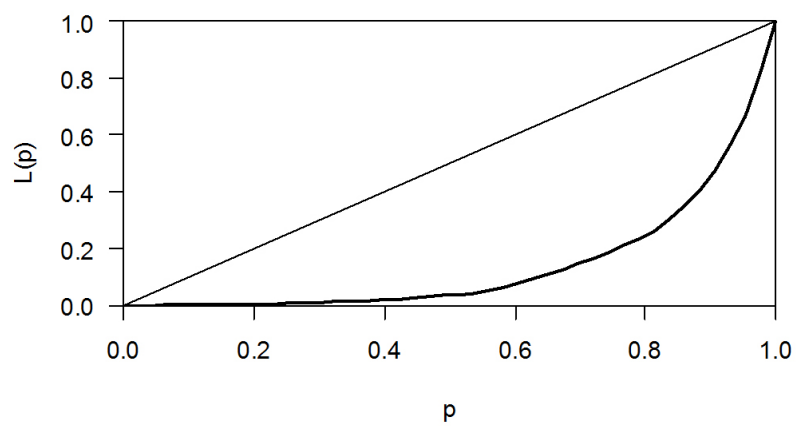

12. ÁBRA

\section{A legjelentôsebb hazai tejfeldolgozók $(\mathrm{N}=43)$ koncentrációelemzése értékesítési adatok alapján 2016-ban \\ (Concentration Analysis of the Major Dairy Processors $(\mathrm{N}=43)$ in Hungary by Sales Data in 2016)}

Forrás (Source): EMIS (2018a)

SZABÓ-SZENTGRÓTI és szerzőtársai (2018) vizsgálatai szerint a tejfeldolgozó szektorban a szakmai szervezetekkel történő együttmúködést leszámítva nem jellemző semmilyen kooperáció. A meglévő néhány valódi együttmúködés az alapanyag-beszerzésre koncentrálódik, de a marketing, értékesítés és a $\mathrm{K}+\mathrm{F}$ területén elhanyagolható vagy nem mérhető az összefogás mértéke. Nem meglepő módon a partnerségek elsőszámú célja a költségcsökkentés, amelynek van kimutatható hatása a tejfeldolgozó vállalatok vezetői szerint. Azt viszont egyikük sem tudta kimutatni, ez miben nyilvánul meg, tehát a vállalatok ezt valószínúleg egyáltalán nem mérik. A magyarországi stratégiai szövetségek nagy része az értékesítés és a marketing területére koncentrál. Ezzel szemben a tejipari szövetségek fóként az alapanyag-beszerzés területén létesülnek.

\section{KÖVETKEZTETÉSEK - ConClusions}

A globális tejtermelés 2017-ben felgyorsult, ami a tejtermékárak csökkenését okozza. A kínálat bővülése várhatóan folytatódik 2018-ban, ami a tejtermékek árának további mérséklődését vetíti előre. A világpiaci árakat 2018-ban egyéb események is befolyásolják. Ilyen például az új-zélandi aszály, az USA esetleges kilépése a NAFTA-ból vagy a szigorodó környezetvédelmi szabályozás Kínában, ahol bizonyos régiókban (zónákban) megtiltják az állattartást.

Az EU tejtermelése 2018. május közepéig a szezonalitásnak megfelelően tovább nő. A tejkínálat a szezonális csúcsot a legtöbb tagországban 2018 májusában éri el, de Franciaországban és Olaszországban ennél korábban, míg az északkeleti tagországokban ennél később. A tej- és tejtermékágazatban a vaj iránti erőteljes kereslet következtében soha nem látott mértékben elszakadt egymástól a zsír és a fehérje ára. Mivel az EU-ban a tejtermelés növekedése 2018-ban is folytatódik, a vaj- és soványtejpor termelése tovább emelkedik. A nyerstejért fizetett termelői árakat 2018-ban befolyásolja a vaj és a sajt iránt jelentkező erős kereslet és a tejfehérje viszonylag alacsony ára. A tejtermékek piacán tapasztalható nehéz helyzet következményeként a sovány tejpor állami intervenciós készletei 2017-ben közel 400 ooo tonnára nőttek az EU-ban, ami a piacra gyakorolt jelentős nyomás kockázatával jár, ez pedig hátrányosan befolyásolná a tejtermékek árait. A Tanács 2018. január 29-én úgy döntött, hogy ideiglenesen módosítja a sovány tejporra vonatkozó állami intervenciós mechanizmus múködését. A Tanács nevezetesen úgy határozott, hogy a sovány tejpor rögzített áron történő felvásárlására vonatkozó mennyiségi korlátozást 2018ra nullában állapítja meg. A készletek jelenlegi nagyon magas szintjére tekintettel megszünt a sovány tejpor rögzített áron történő automatikus felvásárlása. A biztonsági háló azonban így is múködik majd, mivel az EU pályázati eljárás útján továbbra is felvásárolhat rögzített áron 
sovány tejport, de eseti alapon eldöntheti, hogy milyen mennyiségben és milyen árszinten vásárol (EURÓPA TANÁCS, 2018).

Az OECD - FAO (2018) szerint Kína szerepe a tejtermékek terén kulcsfontosságú tényező lesz a következő években, ahol a belső termelésben és fogyasztásban megfigyelhető bármilyen kismértékủ változás nagy hatással lehet a világpiacra. Az EU-ban a specializáció és a tejpiaci újraelosztás van középpontban, mivel a tejkvótát 2015 áprilisában eltörölték. Többek között Hollandia, Németország, Dánia, Franciaország és Olaszország is környezetterhelési akadályokkal küzd, melyek visszafoghatják vagy korlátozhatják a tejtermelés növekedését. A keresletbővülést és az exportlehetőségeket nagymértékben befolyásolja majd a jelenleg is kérdéses szabadkereskedelmi és regionális kereskedelmi egyezmények kimenetele. Oroszország kereslete várhatóan az embargó teljes megszűnését követően sem tér vissza az azt megelőző szintre. A globális termelést a jövőben továbbra is előre nem látott időjárási tényezők befolyásolhatják, mivel a klímaváltozás megnöveli az áradások, az aszályok és a különböző állati betegségek terjedésének kockázatát. Továbbá a környezetvédelmi szabályozás is erősen befolyásolhatja a tejtermelés további helyzetét. A vízgazdálkodási szabályozások területe további krititus pont lehet.

A hazai tejágazatban is egyre inkább jellemzőek a globálisan észlelhető folyamatok. A hazai tejipar erősen koncentrált, az ágazati szintû együttmúködés pedig alacsony. A globális termelés élénkülése, az új exportpiacok megjelenése, az agrárkereskedelem változása és az általános gazdasági liberalizáció egyre versenyképesebb termelést követel meg. A jövőben várhatóan egyre nagyobb szerepet kapnak a horizontális és vertikális együttmúködések az ágazatban, amelyek egyfajta védőhálóként mérsékelhetik a nemzetközi piac felől érkező nyomást.

\section{6. ÖSSZEFOGLALÁS - SUMMARY}

A növekvő egy háztartásra jutó jövedelmek a fogyasztás mennyiségének és szerkezetének változását idézik elő. Az étrendi változások szoros összefüggést mutatnak a gyorsan lezajló urbanizációval. A városba költözés gyakran az életszínvonal emelkedésével jár, amely egyúttal a mezőgazdasági munkaerő eltűnését is eredményezheti. Napjainkban a teljes lakosság több mint fele él városi környezetben, de 2050-re ez az arány a 70\%-ot is elérheti (FAO, 2011). Az élelmiszerfogyasztás szerkezeti változásában a tejnek és tejtermékeknek kitüntetett szerepe van. A magasabb hozzáadott értékủ termékek fogyasztása során elsődlegesen húsfélékre illetve tejre és tejtermékekre váltanak az addig föként növényi alapú étrendet fogyasztó egyének. Az élelmiszerek kínálati oldalát befolyásolják a váratlan időjárási sokkok, amelyek komoly terméskiesést okozhatnak rövidtávon, így kínálati sokként hozzájárulhatnak az élelmiszerárak volatilitásának növekedéséhez. Az utóbbi években a termelés és a fogyasztás közötti rés nem tágult, így csökkent az élelmiszerár és élelmiszerárindex egyaránt, de az élelmiszerárak ingadozása magasabb lett (FAO, 2017). 19602010 között a népesség 230\%-kal emelkedett, míg a húsfogyasztás 450\%-kal, 65 millió tonnáról 290 millió tonnára bővült (OECD - FAO, 2017). Miközben az EU hústermelése várhatóan nem fog nagyobb mértékben változni, és a húsexport is csak kiebb mértékben emelkedik, addig az EU évi tejtermelése folyamatosan, közel 1\%-kal bővül és részesedése a nemzetközi kereskedelembe kerülő tejtermékekből nő a jövőben. A tanulmány célja egy általános tejpiaci helyzetkép felállítása volt. Az elmúlt évek áttekintéséból és a jelenlegi helyzetből kitűnik, hogy a tejágazat jól kivehető irányba haladt az elmúlt időszakban. Az ágazatot gyakorlatilag tisztán a fogyasztói kereslet vezérli, az egyéni szereplők önköltsége nem játszik szerepet a piac árazási mechanizmusában. Ezt tovább fokozza a feldolgozói és kereskedői szegmens magas koncentrációja és erős alkupozíciója. A magasabb piaci integráció lehetőséget biztosít az új típusú exportlehetőségekre, de egyúttal erősebb versenyt is kreál. A jövőben várható a piac további koncentrációja és a verseny erősödése, így az egyéni versenyképesség és az öszszefogás mértéke határozza majd meg a piaci pozíciókat. 


\section{IRODALOMJEGYZÉK - REFERENCES}

AKI (2016): Tej és tejtermékek. Agrárpiaci Jelentések. Agrárgazdasági Kutató Intézet, Budapest. 19 (11) 32.

EMIS (2018a): Contentration Analysis. https://www.emis.com/php/industries/ peer-analysis/concentration-analysis? acc $=30 \& p c=H U \&$ ind $u=3115 \&$ change selected_countries $=1$ (Letöltés dátuma: 2018.10.16.)

EMIS (2018b): Sector Capsule: Drinking Milk Products in Hungary. Euromonitor International 2017. 30. Aug 2017. 1-4.

EMIS (2018c): Sector Capsule: Cheese in Hungary. Euromonitor International 2017. 30. Aug 2017. pp. 1-4.

EMIS (2018d): Sector Capsule: Butter and Margarin in Hungary. Euromonitor International 2017. 30. Aug 2017. 1-4.

Európa Tanács (2018): A Tanács (EU) 2018/147 Rendelete (2018. január 29.) az 1370/2013/EU rendeletnek a sovány tejpor rögzített árú felvásárlására alkalmazandó mennyiségi korlátozás tekintetében történő módosításáról. http://eur-lex. europa.eu/eli/reg/2018/147/oj (Letöltés dátuma: 2018.10.15.)

European Commission (2017): EU Agricultural Outlook for the EU Agricultural Markets and Income 2017-2030. december 2017. Európai Tanács 2018/147/EU rendelete: Council Regulation (EU) 2018/147 of 29 January 2018 Amending Regulation (EU) No 1370/2013 as Regards The Quantitative Limitation for Buying-In Skimmed Milk Powder

EUROSTAT (2018): http://ec.europa.eu/ eurostat/data/database (Letöltés dátuma: 2018.10.15.)

FAO (2011): Looking Ahead in World Food and Agriculture: Perspectives to 2050. (Szerk.: Conforti, P.). Agricultural Development Economics Division Economic and Social Development Department Food and Agriculture Organization of the United Nations. 1-539. http://www.fao.org/ docrep/014/i2280e/i2280e.pdf (Letöltés dátuma: 2018.10.15.)
FAO (2017): FAOSTAT. http://www.fao.org/ faostat/en/ (Letöltés dátuma: 2018.10.15.)

FAO (2018): http://www.fao.org/faostat/ en/\#data/QL (Letöltés dátuma: 2018.10.16.)

Fehér, A. - Szakály, Z. (2010): Az online marketing lehetőségei a tejszektorban. Tejgazdaság. 70 (1-2) 59-67.

Fehér, A. - Szakály, Z. (2013): Az online marketing lehetőségei a tejszektorban - a közösségi háló szerepe. Élelmiszer, Táplálkozás és Marketing. 9 (1) 57-64.

Fehér, A. - Szakály, Z. (2018): A hazai tejszektor online marketing lehetőségei. Tejgazdaság. 75 (1) 55-65.

Global Research \& Data Services (2018a): Milk and Cream Market in Hungary to 2020 - Market Size, Development and Forecast. Published: 4/2016. 1-32.

Global Research \& DataServices (2018b): Milk and Cream Market in Hungary to 2020 - Market Size, Development and Forecast. Published: 4/2016. 1-32.

Harangi-Rákos, M. - Szenderák, J. Popp, J. (2016): Tejpiaci válság az EUban. Állattenyésztés és Takarmányozás. 65 (2) 1-21.

Hemme, T. - Uddin, M. M. - Ndambi, O. A. (2014): Benchmarking Cost of Milk Production in 46 Countries. Journal of Reviews on Global Economics. 3 254270. E-ISSN: 1929-7092/14

IFCN (2016): Long Term Dairy Outlook. http://www.ifcndairy.org/media/ downloads/20160928_IFCN-Article_ Long-term-Dairy-Outlook.pdf (Letöltés dátuma: 2018.10.15.)

Kovács, K. (2016): A hazai tejtermelő tehenészetek gazdasági hatékonyságának vizsgálata. Doktori értekezés. Debrecen, Debreceni Egyetem, Ihrig Károly Gazdálkodás- és Szervezéstudományok Doktori Iskola, https://dea.lib.unideb. hu/dea/bitstream/handle/2437/224533/ Kovacs_Krisztian_ertekezes_titkositott. pdf?sequence $=2$ \&isAllowed $=y \quad$ (Letöltés dátuma: 2018.10.16.)

KSH (2018a): Állatállomány, december (1995-). http://www.ksh.hu/docs/hun/ xstadat/xstadat_eves/i_omaoo3.html (Letöltés dátuma: 2018.10.15.) 
KSH (2018b): A fontosabb állati termékek termelése (1990-). http://www.ksh. $\mathrm{hu} /$ docs/hun/xstadat/xstadat_eves/i_ oma002.html (Letöltés dátuma: 2018.10.15.)

MMO (2018): EU Historical Prices. https://ec.europa.eu/agriculture/sites/ agriculture/files/market-observatory/ milk/pdf/trade-main-competitors_en.pdf (Letöltés dátuma: 2018.10.15.)

OECD - FAO (2016): Dairy and Dairy Products in: OECD - FAO Agricultural Outlook 2016 - 2025. OECD, FAO. 04.11.2016136. https://doi.org/10.1787/ agr_outlook-2016-en

OECD - FAO (2017): OECD-FAO Agricultural Outlook 2017-2026. OECD. Agriculture statistics (database). Paris. https://doi.org/10.1787/agr-outl-data-en

OECD - FAO (2018): OECD-FAO Agricultural Outlook 2017-2026 Dairy and Dairy Product. http://www.keepeek. com/Digital-Asset-Management/ oecd/agriculture-and-food/oecd-faoagricultural-outlook-2017-2026/dairyand-dairy-products_agr_outlook2017-11-en\#page8 (Letöltés dátuma: 2018.10.15.)
Rabobank (2018): Global Dairy Top 20. A shuffling of the Deck Chairs. RaboResearch, Rabobank, 1-4.

Szabó-Szentgróti, E. - Szabó-Szentgróti, G. - Szakály, Z. (2017): Empirical Research on Corporate Strategies in Hungarian Dairy Industry. Applied Studies in Agribusiness and Commerce APSTRACT. 11 (3-4) 169-180. https://doi. org/10.19041/APSTRACT/2017/3-4/23

Szabó-Szentgróti, E. - Szakály, Z. Borbély, Cs. - Szabó-Szentgróti G. (2018): Együttmúködések a magyarországi tejfeldolgozó szektorban - egy empirikus kutatás eredményei. Gazdálkodás. 62 (5) 406-425.

\section{JEGYZETEK $\nRightarrow$ NOTES}

